\title{
The Legal Challenges of International Electronic Contracts in Iraq
}

\author{
Zana Ismael Aziz \\ College of Law, Kirkuk University, \\ Ministry of Higher Education, Republic of Iraq
}

Tel: 964-770-131-4391_E-mail: zana.dezai@yahoo.com

\author{
Zainal Amin Ayub (Corresponding author) \\ School of Law, College of Law, Government \& International Studies \\ Universiti Utara Malaysia \\ 06010 Sintok, Kedah, Malaysia \\ Tel: 60-4-928-8101Ｅ-mail: z.amin@uum.edu.my
}

Khadijah Mohamed

School of Law, College of Law, Government \& International Studies

Universiti Utara Malaysia

06010 Sintok, Kedah, Malaysia

Tel: 60-4-928-8077Ｅ-mail: khadijah@uum.edu.my

Received: June 7, 2017 Accepted: August 15, 2017 Published: September 10, 2017

doi:10.5296/ijssr.v5i2.11332

URL: http://dx.doi.org/10.5296/ijssr.v5i2.11332

\begin{abstract}
The electronic commerce activities raise an emerging legal challenges and problems based on the existing legal systems in Iraq. The traditional commercial relations make the commercial activity on the basis of offer and acceptance relies on the commitment of the seller. For example, to deliver the sales physically and the buyer has to pay the price either in cash or by
\end{abstract}


using tools that are alternative to direct payment-in cash through trade securities or other means of conventional banking fulfillment. However, it is a different story in relation to electronic commerce transactions. The difference is not only in the concept of the commercial activity but also in the tools of its practice and the nature of relations arising under its umbrella. Most activities in the e-commerce activities is carried out online i.e. through the internet or information network. The use of technology is dominant, creating new challenges against the existing legal systems in Iraq. The aim of this article is to study the challenges and problems with regards to electronic contracts in Iraq. It is found that the current law governing the e-commerce in Iraq is the main obstacle for Iraqi consumers to conclude such contracts despite growing importance of e-commerce contract among Iraqis in their daily life. The article suggests amendment to the current legislation governing e-commerce to facilitate the growth of online transaction in Iraq.

Keywords: international electronic contracts, Iraq e-commerce, legal challenges, jurisdiction

\section{Introduction}

In this age of technology, internet communication is inconceivably popular which raised some legal issues (Cotropia \& Petherbridge, 2014) in almost every aspect of human life. Physical commercial dealings, business activities and transactions has now turned into online or electronic transaction, prompting the legislator all over the world to keep abreast with this development by enacting laws to govern electronic transactions (Humairi, 2011).The Iraqi legislator thus follows this development by introducing the Iraqi Electronic Signature and Electronic Transactions Act No.78 of 2012 (Iraqi Electronic Signature, 2012).

One of the most important issues concern and involve the problem of applicable law and the jurisdiction when conflicts arise involving legal international contract (Stern, 2014). This article attempts to examine this issue within the framework of Iraqi's civil law governing the issues of private international law, the Code of Civil Procedure and the Iraqi is Electronic Signature and Electronic Transactions Act 2012.

It is important to note that the Iraqis use the information network extensively after 2003 (Wissam, 2013). Large numbers of people use the network as well as the computers which become one of the necessities of each commercial enterprise and other electronic transactions made via the internet (Msaada, 2007). This actually facilitates the online transaction in a way that it paves the way for the emergence of contracts concluded via the electronic means.

In an international contract, parties are far away from one another (Taha, 2014). There is a tendency for them not to be able to furnish sufficient information necessary for the contract (Alulwan, 2010). The Iraqi legislators had intervened to update the legal provisions on electronic transaction to fulfill the requirement and need of globalization. Suggestion had been made to include legal protection towards the "consumers" both in jurisdictions. One of the most important legislations enacted to regulate the issue of electronic contract is the Iraqi Electronic Signature and Electronic Transactions Act No. 78 of 2012. Iraqi Consumer Protection Act No. 1 of 2010 (Iraqi Consumer Protection Act, 2010) provides the measures to protect the consumer who is considered as a weak party. As stated in its preamble, the Act is 
considered as a framework complementing the legal system in the field of consumer protection. In order to discuss these challenges and problems, this article is divided into two sections. The first section deals with the legal challenges and the second section addresses the legal problems.

\section{Problem Statement}

Since the electronic or online transaction provides large and various opportunities in the light of the current trend of globalization as well as the shift into the digital economy, electronic contract is facing challenges and difficulties that limit its advantages and benefits. One of the most prominent challenges is concerning the legal issues including the conclusion of electronic contracts. The challenges maybe divided into pre and post electronic contracts. Against this background, this article posed questions: what are the challenges facing electronic contracts in Iraq and what is the appropriate and applicable law in such a case; are traditional rules governing conflicts of laws applicable to international contracts will also be applicable to international electronic contracts; does the Iraqi Electronic Signature and Electronic Transactions Act of 2012 adequately tackle the issues in international electronic contract?

\section{Research Methodology}

This research adopts the pure legal research methodology. Being a pure legal research, the study applies the interpretive doctrinal technique, known also as the library research or doctrinal research. The data collected involves the primary and the secondary data (Vibhute, K., \& Aynalem, F., 2009). The primary data was collected from conventions such as the Rome Convention of 1980 and the Brussels Convention of 1968. The primary data was also gathered from statutes such as Iraq Consumer Protection Act No. (1) 2010, Electronic Transactions and Electronic Signature No. (68) 2012, Iraqi Civil Act No. (40) 1951, and law cases relevant to the consumer protection in international electronic contracts. Then, the data is analyzed using the content analysis technique as well as the comparative approaches. The data is analyzed to assess the state of electronic contracts in Iraq in two respects; firstly, the legal challenges facing the development and use of international electronic contracts in Iraq; secondly, the legal problems of international electronic contracts in Iraq in relation to determining the jurisdiction and the applicable law.

\section{Findings and Discussion}

\subsection{Legal Challenges of the International Electronic Contract}

There are several issues and challenges that may be raised at the stage when parties concluding the international electronic contract. One of the issues is the issue of the integrity of the website. All of the details and the legal description of the international electronic contracts are communicated in the virtual world, or described as being conducted between two absents or parties from a distance (Schu, 1997). The parties do not have the opportunity to meet in any physical contractual meeting and mostly never see each other. Maybe, one of them may not be serious in the contractual process. As a result, the admission to the electronic site may form a risk on one of the parties to the transaction as if it may merely be a 
fraudulent website that aims to cheat or phising (Brake, 2014). To avoid such problem, recent legislation in Iraq have resorted to the introduction of the so-called the electronic authentication and ratification bodies (certification authorities) (Adel, 2015). These bodies ensure the process of tracking and disclosing the identification of website. In addition, they record, store and approve electronic transaction concluded between the parties to contract (Kim, 2014). For example, if it has been found that a particular site is unsafe, the customer will be warned and notified with the credibility of the site. These bodies issue electronic certificates and certificates of services.

The task of the documentation authorities is not limited to the authentication of electronic transactions, but it goes further to check the signature and the signing person (website) (Brake, 2014). They match the information to show its real identification such as the credibility of the data of the website (contracting party) and they show the validity of each one of the contracting parties (Gåre, 2015). In addition, protected electronic certificates or user's certificates which are to be their identity cards will be delivered (Kim, 2014).

Another issue is regarding the organizational challenges. Business development through online transaction needs to have changes in the infrastructure represented by the structure, track, and the organizational philosophy of the Iraqi companies (Obed, 2011). There is an urgent need to reorganize its structures and the integration of activities and communicative marketing events related to the electronic transaction as compared to its previous traditional strategy (Tahat, 2005). The working out procedures has to be modernized in a way that goes in line with the advancement information technology.

Besides, the international electronic contracting issues also remain the same as before i.e. the issue of offer and acceptance. The offer and acceptance is considered one of the main difficulties that hinder the formation of contracts through electronic means in the context of electronic commerce (Raghebi, Bagheri and Omidi, 2016). For example, if the parties to contract are $\mathrm{X}$ and $\mathrm{Y}$, how one can be certain that $\mathrm{X}$ has a will to make offer and acceptance and he has already agreed to enter into this contract. Similarly, how one can be sure that if $Y$ claims that someone else has used his e-mail and signed a contract by using his name without his knowledge. In fact, one finds that the electronic signature may limit these obstacles but it does not remove them (Alulwan, 2010).

\subsection{Capacity to Enter into Electronic Contract}

As for the eligibility in electronic contract which is remotely contracted, it may be difficult for one party to the contract to verify the eligibility of the other contracting party (Mormann, 2015). This spatial separation between the parties to electronic transactions may result in the lack of knowledge of all basic information about each other. To legally conclude the electronic contract, the eligibility to enter into contract should be verified. This is why the experts in this field provide some solutions and suggestions to different parties to avoid this drawback (Hanadi, 2015). Some scholars believed that one of the solutions is to adopt a legal system which is to allow the verification of the identity of the parties of the electronic contract by any method that lead to confirm and check the identity (Whitley, Gal, \& Kjaergaard, 2014). This means that through this method, each party can make sure of the 
identity of the other party. For example, the European Directive issued on May 20, 1997 stipulate that for each offer to sell a product or remote service (Directive 97/7/EC, 1997), the supplier should ensure displaying data relating to the identification of his personality such as the name of the facility, the address of the facility, and the electronic mail.

In addition, the consumer is obliged to provide his identification data. Like any other contracts (Kalloniatis et al., 2014), the electronic contract should be issued by the party who have the contractual eligibility in order to legally conclude the electronic contract. If the parties want a lawful contract, they should check the eligibility issued by any available means (McKendrick, 2014). They should also check truthfulness of the data put forward by one of the parties via the internet. The party cannot verify the identification data of the other (Whitley, et.al, 2014), this may certainly affect the validity of the contract.

\subsection{Anonymity}

Like regular contracts, the electronic contract is not legally concluded unless its parties are fully identified, especially their name and their identity (Zacks, 2015). For this reason, a description of the parties to the contract who are materially absent to the council of the contract is pertinent (Gillies, 2016). In conventional transactions, there are many factors and methods to check the true identity of the party (Basho, 2000). As for the electronic commerce and sales and the electronic encryption process (coding), may protect the source of offer and acceptance on networks without external modification to the subject of the contract. It identifies the person who sends the offer and confirms the person who receives it (Clack, Bakshi, \& Braine, 2016). The process is difficult to amend. Thus gives wider guarantees than those existed on paper (Gillies, 2016).

If the message contains an expression of the will, either an offer or an acceptance, how can one check its real attribution of a person to whom it is attributed? The UNCITRAL Model Law developed certain rules regulating the relationship between the person who initiates the electronic message (which includes the expression of the will) and the recipient who is the consignee (UNCITRAL Model Law, 1985). Thus, the electronic message is not only originated from the person who initiates it, but also originated from the same person if it is sent by a person having authority to act on behalf of the originator of the same message in respect of the electronic message. This situation will be applied if the electronic message has been issued by a secured and automated information system to operate automatically by the originator of the message or those who act on his behalf. As for the consignee, he can count on the message and act on the basis that it is actually issued by the consignee (Secretanat, 1991).

\subsection{The Legal Challenges during the Conclusion of the Electronic Contract}

The next stage is the stage of the conclusion of the contract after the process of offer and acceptance. This can be done in many ways according to the content of commercial activity and the means of contracting planned on the site. The most famous means is to include electronic contracts on the web and/or communicating through electronic correspondence like e-mail. In general, the provider, producer, or seller combines with the customer's conditions 
and the agreement will be concluded. Four major problems arise which are discussed below.

\subsubsection{Privacy and Security}

The confidentiality and privacy are considered as challenges that hinder and affect the acceptance of some customers to the idea of shopping online (Mukherjee \& Nath, 2003). Specifically, during the electronic exchange process, some data are needed from the customers such as name, gender, nationality, address, method of payment, and others things. Therefore, there is a need to use special software to maintain the confidentiality and privacy of the exchanged data during the electronic commercial transactions such as Cookies program (Ghosh, Mahdian, McAfee, \& Vassilvitskii, 2015).

\subsubsection{Time and Place of Data Message Received}

The parties to the contract have a practical interest to know where and when is the conclusion of the contract (McKendrick, 2014). When the contract is composed, the two parties become associated with the legal obligations that they have agreed upon. In addition, the contract then also has its legal effects. In many legal systems, the time of formation of a contract may have critical impact in reporting certain issues such as determining the moment the offeror loses his right to withdraw the offer, the right of the offeree to withdraw its acceptance, the time of the transfer of ownership of the goods and the transfer of its sequent destruction or damage in the case of the sale of certain goods (Ramokanate, 2014), and the price which has many consequences of the trade in international stock exchanges (Li, Xie, Chen, Wang, \& Deng, 2014).

The place of the formation of contract may be taken into consideration by the court in the case of litigation (Nasiri, Khalili, \& Dehghandar, 2015), the procedural and objective legal judgments applicable in accordance with the rules of private international law (Al-Qaisi, 2010). Other challenges include the determination of the time and place of entry of the data message in the computer to the recipient "consignee” (Ugwuokpe, 2016), the difficulties encountered the determination of place and time of sending and receiving data messages that include the stages of sending, receiving and entering into the computer, the recording, and finally the consignee retrieves and reads the message (Okazaki \& Barwise, 2011).

\subsubsection{The Condition of the Signature}

The condition of the signature here referred to the authentic electronic contract or mandatory legal power of the contracting means (Chan, 2014). In traditional trade, this includes the signature of the person on the written contract, ordering the goods, or personal evidence (testimony) (Bagherian, Nasaband, Heidari, \& Ebrahimi, 2014). As for the case of the unwritten contracts, evidence from witness is crucial in determining the enforcement of the obligations of the parties after the conclusion of the contract (Grzybek, De Vries, \& Zhang, 2015). Various techniques have been modernized to authenticate the documents electronically sent. Following the proper procedures, this can reduce the probability of the success of unauthorized persons in using some authentication techniques (Buzzi, Gennai, Petrucci, \& Vinciarelli, 2014). However, these methods have to deal with skepticism in terms of legal recognition, especially in countries where the law requires signing a certain handwritten 
document (Razmi \& Afras, 2014). Digital signature is found to have achieved the function of the physical signature (Mashak Zadeh, 2014).

\subsubsection{Barriers of Language and Culture}

The language and culture are considered as the most important challenges that hinder the interaction between many customers and several electronic websites (Abu-Shanab \& Bataineh, 2014). Therefore, there is an urgent need to develop software that will make a quantum leap in the translation of texts into languages understood by customers. There is also a need to take account of cultural barriers, customs, traditions and values so as not to be a hindrance towards the use and understanding of commercial sites (Bagherian et al., 2014).

\subsection{Jurisdictional Problem of the International Electronic Contract in the Iraqi Law}

International jurisdiction of national courts in the field of international private relations law covers all legal issues such as personal status and competence issues of contractual and non-contractual obligations (Humairi, 2011). As the topic of this research is related to contractual obligations, its relevant part will be addressed with reference to the position of that issue in the Iraqi law. According to Article 15 of the Iraqi Civil Law (Iraqi Civil Law, 1951), the jurisdiction is granted to the non-resident foreigners in Iraq within two conditions. The first case is whether the contract is concluded in Iraq. Another one is whether the contract is executed in Iraq. A foreign person can litigate in Iraqi courts in all cases if he/she exists in Iraq according to paragraph (a) of the same Article regardless of the place of the implementation or conclusion of the contract whether it is in Iraq or not. According to Article 15 of the Iraqi civil law, the Iraqi courts achieve the maximum capability of the jurisdiction of the Iraqi courts. Thus, the Iraqi court is regarded as competent in accordance with the controlling place in the following cases; those who claim the right in confronting another person must file a lawsuit in the court of the defendant's address or place of residence (Obed, 2011). This is one of the most important principles of international jurisdiction in different states. It can be done in order to take into account the considerations of justice, the need for stability, and providing the care for the defendant to sue him before his home court (Rifai, 2011).

However, could the competence of the court of the defendant's home be applied in the field of the international electronic contracts? As for the international electronic contracts problem arise because of the parties living in different jurisdictions. Therefore, the parties' face difficulty in delivering claims towards the other party (Hanadi, 2015). The law in the home of the defendant does not sometimes recognize such contracts concluded electronically and he therefore cannot get his rights (Alulwan, 2010). This control is exposed to a series of criticisms regarding its application to the conflicts of the international electronic contracts. These criticisms are due to the difficulty of determining the habitat or place of defendant's residence in case of its location on the internet (Anyu \& Chigbo, 2015). Checking and verifying the identity of the defendant and his place is also difficult, particularly in the case in which the contractor is not obliged to make personal data such as the name and the address (Fatema, Lewis, O’Sullivan, Morrison, \& Al-Mazed, 2015). 
The researchers believed that existing traditional legal concepts cannot be applied to international electronic contracts because of the criticisms that have been mentioned. If those rules have been applied, they do not give adequate protection for Iraqi consumers when concluding the international electronic contracts. The voluntary submission is the defendant's acceptance in the lawsuit in which the plaintiff implicitly or explicitly chooses competence court of a particular state despite the lack of its competence (Tahat, 2005). This principle in determining the competent court is contrary to the principle of state sovereignty. It is also contrary to leave the judicial principles in the hands of the individuals to choose the competent court to consider the lawsuit (Al-Ajmi, 2011).

However, this idea is exclusive in the modern era. The age of technology and the progress of modern means of communication make the idea of the sovereignty of the state and the reduction of the individuals' control over the judiciary through their choice of the competent court in the international relations slowly vanish. This is due to the emergence of technology and the speed of concluding the contracts without the physical presence of the parties who use the internet (Al-Qaisi, 2010). In addition, there is no longer an obstacle with respect to the adoption of the principle of the freedom to choose the competent court (Poillot, 2014). When the parties choose certain courts to settle their conflicts, the aim of this act is to choose the most suitable judiciary in a state in which its litigation is fair and its laws and provisions are well-developed (Obed, 2011). To authenticate the contractors' agreement in determining the competent court that considers the conflict, it is required that a number of conditions should be provided. These conditions are as follows -

1-The need for a serious link between the conflict and the court agreed to assess its competence.

2-There should be a legitimate interest to make the jurisdiction of a certain court.

3-The agreement should not imply cheating (Lekka, 2016).

It is important to note that this control is also subjected to criticism since it is characterized as arbitrary condition. The contractor may not have a look at this condition before pressing the approval icon.

When the contract lacks an agreement in which jurisdiction is determined by the parties to the legal relationship in the case of international contracts or the inapplicability of the control of the court of the defendant's place, the courts usually start searching for the control of the jurisdiction of the court of the place of conclusion of the contract or its implementation (Al-Qaisi, 2010). If the contract was concluded, the court of the place of concluding the contract specializes in the lawsuit that arises from the contract. It does not matter then that the contract has been carried out or enforceable abroad. In addition, a court of a state can specialize in implementing the contract regardless of the place of conclusion of the contract (Boiled \& Saraireh, 2014). Determining the place of the conclusion of the contract or the place of its implementation execution is not easy in the contracts concluded via the internet (Gonçalves, 2015). These contracts are considered between attendants in terms of time, and 
between absentees in terms of the place. If the place of offeror's acceptance is known, that place is considered the place of the conclusion of the contract. Therefore, the court of the place of the conclusion of the contract specializes in the lawsuit whether the contract has been implemented or not (Lloyd, 2017).

As for determining the place of implementation of the contract, regardless of the place of the conclusion of the contract, it depends on the intent of the parties and the nature of the contract to know the place of implementation of the contract. Thus, paying by providing a credit card to the seller and providing services such as legal or medical consultation via the internet is regarded as an implementation of the contract in the state that benefits from such service (Almasoud, 2008). Then, the court of the state of the beneficiary is the competent court. As for the supplier of electronic services in the contracts of electronic services, he just has to file a lawsuit before the courts of the user's habitat (Almasoud, 2002). Concerning the international contract, when the problem of conflict of laws is raised, the clear will of the parties is applied as to what has been agreed upon when concluding the contract. In the case disagreement, the court applied the principle of the hidden will where the court clarifies the intention of the parties based on circumstances occurred when the parties concluding the contract (Erin, 2005). Accordingly, the law of the place of the implementation of the contract, or the law of the state of the conclusion of the contract is applied to the parties to the contract in its national currency.

The Iraqi law of the electronic transactions does not address the issue of the applicable law (conflict of laws). Therefore, the provisions of the Civil Code, the Evidence Act, and the Code of Civil Procedure are applied instead. In the issue of the applicable law, the provision of Article 25 of the Iraqi Civil Code of 1951 will be applied (Iraqi civil law, 1951). It governs the issue of the conflict of laws regarding the international contracts. Its provision is as follows -

1. The law of the state, where there is a common habitat of the contractors in case of the unity of their habitat, is applied to contractual obligations. If their habitat is different, the law of the state in which the contract is concluded is applied unless the two contractors agreed or according to the circumstances it has been shown that another law is intended to be applied.

2. The law of the location of the property is applicable to concluded contracts.

It is clear from this provision that the Iraqi law adopts the principle of the law of the will progressively. First, it stipulates the application of the law of the common habitat of the contractors in the case of the unity of their habitat. If their habitat is different, the law of the state in which the contract is concluded has been applied and the contractors feel free to agree on the law applicable to the conflicts of the contract.

Another issue is the difficulties on the explicit choice of the law of the contract. Electronic contracts are considered as contracts that are remotely concluded. Electronic websites pages related to the contracting have been designed in a way that includes the word 'yes' in Arabic or in any other famous languages in communication such as English and French (Alférez \& 
Francisco, 2008). It is envisaged that the person clicks the assent button on the computer against his will or he does that by mistake. This means that the other party receives acceptance to an offer. The contracting shall be deemed to be right (Rothchild, 1998). Thus, it has been acted on this basis with respect to the contractual obligation towards the implementation of the contract. In such case, confirming the will of the first party to choose the designated law may be characterized as flawed.

On the other hand, the problem is complicated in the case in which the electronic contracting is concluded by electronic devices alone without the human intervention (Lahlou \& Matousekova, 2010). For example, this can be done when the devices are programmed to complete the contracting process in the case of the need for goods running out of the stores. It is very difficult to attribute this will to the contractor due to the presence of legal difficulties regarding this issue, especially with the absence of the explicit provision that makes such conduct lie in the rule of the human act, or at least make it attribute to the beneficiary of the contracting (Healy, 2008). The implicit choice of the law applicable to the conflicts to the international contract is considered as a second phase that comes after the explicit selection phase (Ruhl, 2011). The court thus depends on certain criteria to know the will of the parties.

In the international electronic contracts, it cannot be affirmed that there is a certain domicile for the contractors as well as a certain place for the conclusion or implementation of the contract since these contracts are concluded in the cosmic space (Little, 2012). Moreover, it is possible for the offeror to receive the acceptance though he is in an area that is not subject to the law of a particular state like the outer space or the high seas, especially with the presence of laptops (Zhang, 2008). These devices can be carried to any place. One can travel with these devices as well. This applies to the parties' country of residence. Also, it is difficult to determine the issue of regarding on the currency type by which the contract is implemented in the field of international electronic contract (Rogerson, 2013). It is important to note that the electronic money like BitCoin has been entered into the field of transaction (Tasca, 2015; Trautman, 2015). The electronic money is regarded as a currency that is not owned by a particular state (Ruhl, 2011). The language of the contract is considered as one of the criteria upon which the court relies when the parties are silent about determining applicable law (Schwartz \& Scott, 2003). However, the predominant language which is largely used in communication and dealing via the internet is English (Abu Samak, 2016). It is an international language in a way that it cannot be attributed to a particular state. Thus, the court faces a number of laws in order to have the applicable law to the lawsuit in which the interests of the parties may be affected whatever the court is being diligent. Therefore, it is difficult to rely on it as a criterion in this regard (Paunio, 2016).

One can state that the provisions provided in the Civil Transactions Act of 1951 not afford a solution to this problem. When the legislator developed these provisions, they were intended to solve the traditional international contracts. These criteria were perfectly valid for its case as well. When these difficulties emerge, the jurisdiction tried to develop solutions for that issue such as the proposal to develop a model law organizing the electronic commerce. Nevertheless, this proposal does not offer a diligent solution since it is difficult to agree on such a law as a result of different political and economic ideologies. That agreement can take 
time in the stages of the study. It can also take time to agree upon with the existence of the problem and its need to resolve especially with the increasing and growing dealing in electronic commerce.

\section{Recommendation and Conclusion}

Electronic commerce is considered one of the modern means which include trading the electronic goods and services by using electronic means. The electronic commerce activities and legal relations arising therefrom raise many challenges and problems of the existing legal systems in Iraq. One of the most important effects is the legal challenges revolving around electronic contract in Iraq. There are some special challenges in Iraq to conclude electronic contracts. The most prominent challenges that hinder the way of electronic contract in Iraq is probably that the customers or clients do not accept the idea of online purchases due to the fact that they could not have ignored the risk related to security of data, the description and the quality of the goods and services, the lack of ability to test the goods before purchasing and so much more. Another challenge is that the infrastructure to complement to advancement of IT in Iraq is not very accommodating due to lack of infrastructure because of war. The companies those are willing to invest in electronic commerce also very limited due to the situation in Iraq. Again, the problem of the slow pace of the internet network as well as the difficulty of movement and transportation hampers the development of electronic commerce in Iraq.

Apart from physical infrastructure, the legal infrastructure to govern electronic commerce is not up to date and yet to be tested in any Iraqi court of law. The Iraqi legislator should make laws for the dissemination of information awareness among members of the community and the establishment of training methods working on encouraging the individuals to use modern means of communication in the conclusion of the various contracts. Furthermore, the contracting via the internet poses many challenges. One of the most important challenges is the challenges in the field of the fulfillment of the electronic contracts.

Thus, the legislator is required to intervene to address these challenges through the issuance of legislations in the field of electronic transactions as well as amending the existing legislation to make it appropriate with the electronic contracts. These legislations should keep pace with developments occur in the field of fulfillment the proof of the electronic contracts. A specialized unit for electronic commerce should be established in the Ministry of Commerce that follows up all the activities relevant to electronic commerce which will be held at the regional and international levels. The dissemination of awareness of the importance of electronic commerce technologies and their practical applications is urgent.

\section{Acknowledgment}

The author would like to express gratitude to the University of Kirkuk, Republic of Iraq and the Ministry of Higher Education, Republic of Iraq for the funding of the $\mathrm{PhD}$ research of the 1st author that makes the publication of this article possible. 


\section{References}

Abu Samak, Zeinab. (2016). Exploration of Jordanian English Language Teachers' Attitudes, Skills, and Access as Indicator of Information and Communication Technology Integration in Jordan. ( Unpublished PHD dissertation). University of Florida State. USA.

Abu-Shanab, E., \& Bataineh, L. Q. (2014). Challenges facing e-government projects: how to avoid failure. International Journal of Emerging Sciences, 4(4), 207-217.

Adel, Ahmed. (2015).The courts in Iraq. Kinds, degrees, duties. The Journal of Legal Science, 49(3), 6-7.

Al-Ajmi, Falah. (2011). Civil Protection for the Consumer in the Electronic Contract. (Unpublished Master dissertation). University of the Middle East.

Alférez, F. G., \& Francisco, J. (2008). The Rome I Regulation: much ado about nothing. In The European Legal Forum, 6-7.

Almasoud, Sultan. (2008).The alignment of the Saudi legal system with the international rules of electronic commerce. (Unpublished PHD dissertation) University of Hull .Iraq.

Al-Qaisi, Amer. (2010). The legal protection of the consumer. Jordan, Oman: Dar scientific and Dar culture.

Alulwan, Ali. (2010). Problems of Signing Electronic Contract. Zarqua University, Faculty of Law, 67(4), 1-10.

Anyu, J. N., \& Ofong, C. (2015). Teething problems in litigation and regulation of e-commerce. International Journal of Organizational Innovation (Online), 7(3), 46- 47.

Bagherian, A., Nasaband, Y. E., Heidari, H., \& Ebrahimi, M. (2014). The Role of Electronic Signature in the Third Millennium of the Development of International Trade Transactions. International Journal of Information Systems and Social Change (IJISSC), 5(2), 39-52.

Basho, K. (2000). The licensing of our personal information: Is it a solution to Internet privacy. California Law Review, 1507-1545.

Boiled, Muhannad \& Saraireh, Mansour. (2014). Applicable to electronic consumer contracts of an international character of law. Jordan, Middle East University, Sharia law and science studies, 41(6), 1346-1351.

Brake, D. (2014). Sharing our lives online: Risks and exposure in social media. Springer.

Buzzi, M., Gennai, F., Petrucci, C., \& Vinciarelli, A. (2014). E-Government Services: Italian Certified Electronic Mail. Retrieved from www.iit.cnr.it/sites/default/files/Buzzi\%20IADIS_PEC

Chan, T. D. (2014). Electronic signature: towards a seamless integration of legislation and technology. HKU Theses Online (HKUTO), 9-11. 
Clack, C. D., Bakshi, V. A., \& Braine, L. (2016). Smart Contract Templates: foundations, design landscape and research directions. arXiv preprint arXiv:1608.00771,12-13.

Cotropia, C. A., \& Petherbridge, L. (2014). The Dominance of Teams in the Production of Legal Knowledge. Yale LJF, 124, 16-18.

Directive 97/7/EC of the European Parliament and of the Council of 20 May 1997 on the protection of consumers in respect of distance contracts.

Erin Ann, O. H. (2005). Choice of law for internet transactions: The uneasy case for online consumer protection. University of Pennsylvania Law Review, 1883-1950.

Fatema, K., Lewis, D., O'Sullivan, D., Morrison, J. P., \& Mazed, A. A. (2015, December). Authorising contract based access to personal data in the cloud. In Utility and Cloud Computing (UCC), 2015 IEEE/ACM 8th International Conference on, 559-564.

Gåre, M. L. (2015). User-Based Information Search across Multiple Social Media (Master's thesis, UiT Norges arktiske universitet).

Ghosh, A., Mahdian, M., McAfee, R. P., \& Vassilvitskii, S. (2015). To match or not to match: Economics of cookie matching in online advertising. ACM Transactions on Economics and Computation, 3(2), 11-12.

Gillies, L. E. (2016). Electronic commerce and international private law: A study of electronic consumer contracts. Routledge.

Gonçalves, A. (2015). The e-commerce international consumer contract in the European Union. Masaryk UJL \& Tech., 9, 4-5.

Grzybek, J., De Vries, T. I. N. A., \& Zhang, Y. (n.d.). Achieving flexibility in contracting by using vague terms in international business contracts: A comparative approach from the perspective of Common law, German, Polish and Chinese Law. Flexibility in Contracting, 142-143.

Hanadi, Daou. (2015). The contract Electronic. (Unpublished PHD dissertation). University of Azhari Leader.

Healy, J. J. (2008). Consumer Protection Choice of Law: European Lessons for the United States. Duke J. Comp. \& Int'l L., 19, 534-535.

Humairi, H. (2011). The jurisdiction of Iraq. Amman Legal Network, 23, 4-5.

Iraqi civil law. (1951). Retrieved September 27, 2016, from http://www.legislations.gov.iq

Iraqi Consumer Protection Act. (2010). Retrieved September 27, 2016, from http://www.legislations.gov.iq

Iraqi Electronic Signature and Transactions Act. (2012). Retrieved September 27, 2016, from http://www.legislations.gov.iq 


\section{Macrothink}

International Journal of Social Science Research

ISSN 2327-5510

2017, Vol. 5, No. 2

Kalloniatis, C., Mouratidis, H., Vassilis, M., Islam, S., Gritzalis, S., \& Kavakli, E. (2014). Towards the design of secure and privacy-oriented information systems in the cloud: Identifying the major concepts. Computer Standards \& Interfaces, 36(4), 759-775.

Kim, N. S. (2014). Situational Duress and the Aberrance of Electronic Contracts. Chi.-Kent L. Rev., 89, 264-265.

Lahlou, Y., \& Matousekova, M. (2010). Chronicle of Conflict of Laws Applied to Business. Int'l Bus. LJ, 610-611.

Lekka, K. (2016). Is a mandatory binding arbitration clause in a prefixed contract consistent with the prerequisite of voluntarily agreement? Matters of validity and award's recognition and enforcement under the NY Convention.

Li, X., Xie, H., Chen, L., Wang, J., \& Deng, X. (2014). News impact on stock price return via sentiment analysis. Knowledge-Based Systems, 69, 14-23.

Little, L. E. (2012). Internet choice of law governance. In China Private International Law Forum, 11-12.

Lloyd, I. (2017). Information technology law. Oxford University Press.

Mashak Zadeh, S. A. R. K. A. (2014). The Role of Electronic Signature in the Third Millennium of The Development of International Trade Transactions. Indian Journal of Fundamental and Applied Life Sciences, 1634-1635.

McKendrick, E. (2014). Contract law: text, cases, and materials. Oxford University Press (UK).

Mormann, M. D. (2015). DPH Consolidated Contract Addendum.

Msaada, Nael. (2007). Jurisdiction and Legislative for decades electronic in Jordanian law. Manara, 13(2), 3-2.

Mukherjee, A., \& Nath, P. (2003). A model of trust in online relationship banking. International journal of bank marketing, 21(1), 5-15.

Nasiri, N., Khalili, N. A., \& Dehghandar, M.(2015). An Investigation into the Succession of Offer and Acceptance in Electronic Contracts. Routledge.

Obed, Muwaffaq. (2011). Civil protection for the consumer - a comparative study, Bagdad: Sanhouri library.

Okazaki, S., \& Barwise, P. (2011). Has the Time Finally Come for the Medium of the Future? Journal of Advertising Research, 51(50th Anniversary Supplement), 59-71.

Paunio, E. (2016). Legal certainty in multilingual EU law: language, discourse and reasoning at the European Court of Justice. Routledge.

Poillot, E. (2014). The European Court of Justice and General Principles Derived from the Acquis Communautaire. Oslo Law Review, 1(1), 67-77. 
Raghebi, M. A., Bagheri, P., \& Omidi, R. (2016). Legal principles on applying authority Parliament on electronic contracts. Journal of Current Research in Science, (2), 178-177.

Ramokanate, L. L. (2014). A legal framework for the treatment of input errors in electronic contracts (Doctoral dissertation). North-West University.

Razmi, M., \& Afras, M. (2014). Poition of Electronic Evidence in Iran Law and International Documents. Indian J. Sci. Res, 5(1), 425-431.

Rifai, Badran. (2011). The consumer in the international private law contracts. Egypt: House legal books.

Rogerson, P. (2013). Problems of the Applicable Law of the Contract in the English Common Law Jurisdiction Rules: The Good Arguable Case. Journal of Private International Law, 9(3), 387-411.

Rothchild, J. (1998). Protecting the Digital Consumer: The Limits of Cyberspace Utopianism. Ind. $L J, 74,893-894$.

Ruhl, G. (2011). Consumer Protection in Choice of Law. Cornell Int'l LJ, 44, 568-569.

Schlossberger, O. (2015). Anti-Money Laundering. EU Press.

Schu, R. (1997). The Applicable Law to Consumer Contracts Made Over the Internet: Consumer Protection Through Private International Law. International Journal of Law and Information Technology, 5(2), 192-229.

Schwartz, A., \& Scott, R. E. (2003). Contract theory and the limits of contract law. Yale Law Journal, 541-619.

Secretanat. (1991). C. UNCITRAL Model Law on International Commercial Arbitration.

Stern, J. Y. (2014). Property, Exclusivity, and Jurisdiction. Virginia Law Review, 111-181.

Taha, Abrahim. (2014).International electronic Contract: Applicable judicial jurisdiction over their disputes and problems with the law (Study under Sudanese law). Forum Omani law, 2, 3-5.

Tahat, D. (2005). Regulating Electronic Contracting in Jordan. Regulating Electronic Contracting in Jordan, 5-7.

Tasca, P. (2015). Digital currencies: Principles, trends, opportunities, and risks. Trends, Opportunities, and Risks (September 7, 2015), 13-14.

Trautman, L. J. (2015). E-Commerce, Cyber, and Electronic Payment System Risks: Lessons from Paypal. Cyber, and Electronic Payment System Risks: Lessons from Paypal (August 25, 2015), 16-17.

Ugwuokpe, K. (2016). The Bill of Lading in an Era of Electronic Commerce: Legal Developments and the Reform Options for Nigeria. (Unpublished master dissertation). Dalhousie University. 


\section{Macrothink}

International Journal of Social Science Research

ISSN 2327-5510

2017, Vol. 5, No. 2

Uncitral Model Law on International Commercial Arbitration. (1985). Retrieved from https://www.uncitral.org/pdf/english/texts/arbitration/ml-arb/07-86998_Ebook.pdf

Vibhute, K., \& Aynalem, F. (2009). Legal Research Methods. Teaching Material.

Whitley, E. A., Gal, U., \& Kjaergaard, A. (2014). Who do you think you are\&quest; A review of the complex interplay between information systems, identification and identity. European Journal of Information Systems, 23(1), 17-35.

Wissam, Abdullah. (2013). The principles of private international law. Rafidain of Law Journal, 16(57), 3-4.

Zacks, E. A. (2015). Shame, Regret, and Contract Design. Marquette Law Scholarly Commons, 93(3), 726-735.

Zhang, M. (2008). Contractual Choice of Law in Contracts of Adhesion and Party Autonomy. Akron L. Rev., 41, 122-123.

\section{Copyright Disclaimer}

Copyright for this article is retained by the author(s), with first publication rights granted to the journal.

This is an open-access article distributed under the terms and conditions of the Creative Commons Attribution license (http://creativecommons.org/licenses/by/3.0/). 